\title{
Feeding ecology and ontogenetic dietary shift of yellowstripe goatfish Mulloidichthys flavolineatus (Mullidae) at Reunion Island, SW Indian Ocean
}

\author{
Joanna Kolasinski ${ }^{1, *}$, Patrick Frouin ${ }^{1}$, Amélie Sallon ${ }^{1}$, Karyne Rogers ${ }^{2}$, \\ Henrich J. Bruggemann ${ }^{1}$, Michel Potier ${ }^{3}$ \\ ${ }^{1}$ Laboratoire d'Ecologie Marine, Université de La Réunion, 15 avenue René Cassin, BP 7151, \\ 97715 Saint-Denis messag Cedex 9, La Réunion, France \\ ${ }^{2}$ National Isotope Centre, GNS Science, 30 Gracefield Road, PO Box 31 312, Lower Hutt, New Zealand \\ ${ }^{3}$ Institut de Recherche pour le Développement, Centre de La Réunion, UR 109 Thetis, BP 172, 97492 Sainte Clotilde, \\ La Réunion, France
}

\begin{abstract}
We analyzed stomach contents and muscle isotopic composition $\left(\delta^{13} \mathrm{C}, \delta^{15} \mathrm{~N}\right)$ of yellowstripe goatfish Mulloidichthys flavolineatus from a coral reef to investigate size-related dietary changes and resource or habitat partitioning. Juveniles $(<12 \mathrm{~cm}$ total length [TL]), young adults $(12 \leq$ $\mathrm{TL}<17 \mathrm{~cm}$ ) and adults $(\geq 17 \mathrm{~cm}$ TL) showed a high diet overlap, especially between juveniles and young adults. According to stomach contents analysis, $M$. flavolineatus widens its prey spectrum with increasing size from a common prey pool that includes polychaetes, tanaids and harpacticoid copepods. We observed a significant increase in $\delta^{13} \mathrm{C}$ values (from $-17.1 \pm 0.5 \%$ or juveniles to $-10.7 \pm$ $0.8 \%$ for adults), which were correlated to fish size. Adults $\left(\delta^{15} \mathrm{~N}\right.$ mean of $11.1 \pm 1.8 \%$ o) were one trophic level above juveniles and young adults $(7.7 \pm 0.5$ and $7.4 \pm 0.5 \%$, respectively). These patterns of isotopic changes confirmed ontogenetic dietary shifts. However, trophodynamics can be influenced by physiological factors such as growth and sexual maturity. M. flavolineatus shift from a pelagic to a macrobenthic diet, which is equilibrated at the adult stage. Results from combined stomach contents (prey volume) and stable isotope analyses suggested a dominant contribution of polychaetes (macrofauna), possibly through selective feeding. Conversely, on the basis of prey volume and stable isotope data, meiofauna did not feature significantly in the diet despite their high abundance in stomachs. Two adult groups were distinguished based on their $\delta^{15} \mathrm{~N}$ values $(11.9 \pm 0.8$ and $7.8 \pm 0.6 \%$ ), indicating possible stage-specific partitioning in habitat use inside the reef.
\end{abstract}

KEY WORDS: Yellowstripe goatfish · Ontogenetic diet shift · Stomach contents · Stable isotopes Mixing model $\cdot$ Southwestern Indian Ocean

\section{INTRODUCTION}

Goatfish (Perciformes, Mullidae) are widespread tropical and subtropical fish, and are particularly abundant in shallow-water ecosystems (Munro 1976, McCormick 1995) that serve as nurseries or habitats. Numerous fish species are found in these environments mainly due to favorable conditions both in terms of prey availability and shelter (Parrish 1989,
Robertson \& Blaber 1992). Of the 10 goatfish species inhabiting Reunion Island reefs (southwestern Indian Ocean), the yellowstripe goatfish Mulloidichthys flavolineatus is the most common (Letourneur 1996). Despite their importance for artisanal fisheries, little is known about the feeding ecology, recruitment and habitat preferences of this species. Such data are critical for designing efficient conservation and management policies. 
Knowledge of the trophic interactions between fish and their food resources is of immediate significance to understanding processes that structure shallow-water tropical communities. A number of studies on goatfish diets are reported from the Pacific (Sorden 1982, Lukoschek \& McCormick 2001, Sampey et al. 2007), the tropical West Atlantic (Munro 1976, Humann \& DeLoach 2002), the Mediterranean and the Red Sea (Ben-Eliahu \& Golani 1990, Golani \& Galil 1991, Wahbeh 1992). Published data from the Indian Ocean are scarce and concern only the genus Upeneichthys (Platell et al. 1998). Sympatric mullid species can greatly differ in their depth distribution, foraging substratum selection and feeding modes (Gosline 1984, McCormick 1995, Platell et al. 1998). While main food items vary widely among species, all Mullidae are benthic carnivores, using their sensory hyoid barbels to drive out prey. Mulloidichthys flavolineatus is considered to be a specialist benthic predator, foraging mainly on sediments around reefs (McCormick 1995). Past studies from the Hawaiian Midway Islands (Sorden 1982) and the northern Red Sea (Ben-Eliahu \& Golani 1990, Wahbeh 1992) provide general descriptions of prey items consumed by $M$. flavolineatus. While Sorden (1982) and Ben-Eliahu \& Golani (1990) focused on polychaetes in stomach contents, Wahbeh (1992) investigated the overall diet of M. flavolineatus and reported the presence of fish eggs, nematodes, molluscs and arthropods. Wahbeh (1992) also reported differences in diet composition between adults of different age groups: while fish eggs and arthropods were dominant in younger $M$. flavolineatus, nematodes and molluscs were more commonly found in older individuals. Such ontogenetic changes in diet composition have been shown to be important for many fish species, in particular for benthic carnivores (McCormick 1998, Lukoschek \& McCormick 2001). To date, ontogenetic dietary changes in early post-settlement $M$. flavolineatus have not been reported.

Stomach content analysis provides a taxonomic resolution of an individual's recent (hours to days) feeding habits. However, this approach only presents a snapshot of the food habits and includes some uncertainties when prey identification is difficult or impossible due to digestion. More recently, combined stomach content and stable isotope analyses have been used in trophic ecology (e.g. Wells et al. 2008). Stable isotopic compositions of consumer tissues can often be predictably related to stable isotopic compositions of the corresponding diet (DeNiro \& Epstein 1978). This approach relies on the consistent enrichment of stable carbon and nitrogen isotopes that occurs with each successive trophic level due to isotopic fractionation during assimilation (e.g. Minagawa \& Wada 1984). The mean trophic shift of consumers' tissue relative to their food source is around 2.9 to $3.8 \%$ for $\delta^{15} \mathrm{~N}$ values and 0.0 to $1.5 \%$ o for $\delta^{13} \mathrm{C}$ values in marine systems (Michener \& Schell 1994, Vander Zanden \& Rasmussen 2001).

Unlike stomach content analysis, stable isotope ratios of an organism's tissue provide information on the time-integrated assimilated diet. If the isotopic composition of available prey differs with habitat, stable isotopes can provide a powerful tool to investigate animal movement (Fry \& Arnold 1982, Hesslein et al. 1991). This approach depends on distinctive isotopic signatures of primary producers found in specific habitats which are propagated through a local food web (Michener \& Schell 1994) and has been successfully used to trace the early life stages of fish (Herzka et al. 2002a) and migration of shrimp (Fry 1983, Fry et al. 2003). Stable isotope ratios can thus serve as natural chemical tracers for discriminating recent immigrants from those that have partially or fully equilibrated to the isotopic composition of the prey consumed in a new habitat (Fry et al. 1999, Herzka et al. 2002b).

We investigated the feeding ecology of Mulloidichthys flavolineatus from a coral reef at Reunion Island. A wide size range of individuals was sampled across a fringing reef in order to describe possible ontogenetic changes that occur in their diets. Using stomach content and stable isotope analyses, the present study was designed to address the following questions: (1) Are there ontogenetic variations in diet composition of $M$. flavolineatus? If so, (2) can ontogenetic change patterns be used to infer possible resource or habitat partitioning within the M. flavolineatus population?

\section{MATERIALS AND METHODS}

Study site and sample collection. Reunion Island $\left(21^{\circ} 07^{\prime} \mathrm{S}, 55^{\circ} 32^{\prime} \mathrm{E}\right)$ is situated in the SW Indian Ocean, $800 \mathrm{~km}$ east of Madagascar (Fig. 1) and is characterized by a tropical oceanic climate with a wet summer season extending from January to April. The continental shelf is very narrow, and coral reefs fringe less than $10 \%$ of the coastline. The present study was carried out at the La Saline fringing reef ( $4 \mathrm{~km}$ long, $500 \mathrm{~m}$ maximum width), located on the west coast of the island (Fig. 1). Soft-bottom habitats are composed of coarse sand scattered with coral fragments.

After an offshore pelagic larval phase, Mulloidichthys flavolineatus cross the reef front at $10.7 \pm$ $0.9 \mathrm{~cm}$ total length (TL) to recruit in back-reef and inner-reef flat habitats of Reunion Island (Durville 2002). Post-larval M. flavolineatus recruit to the La Saline reef during the summer season (Durville 2002). Fish were caught in March 2007 inside a $0.5 \mathrm{~km}^{2}$ area (Fig. 1) using a $3 \times 10 \mathrm{~m}$ wide barrier net with $1 \mathrm{~cm}$ 


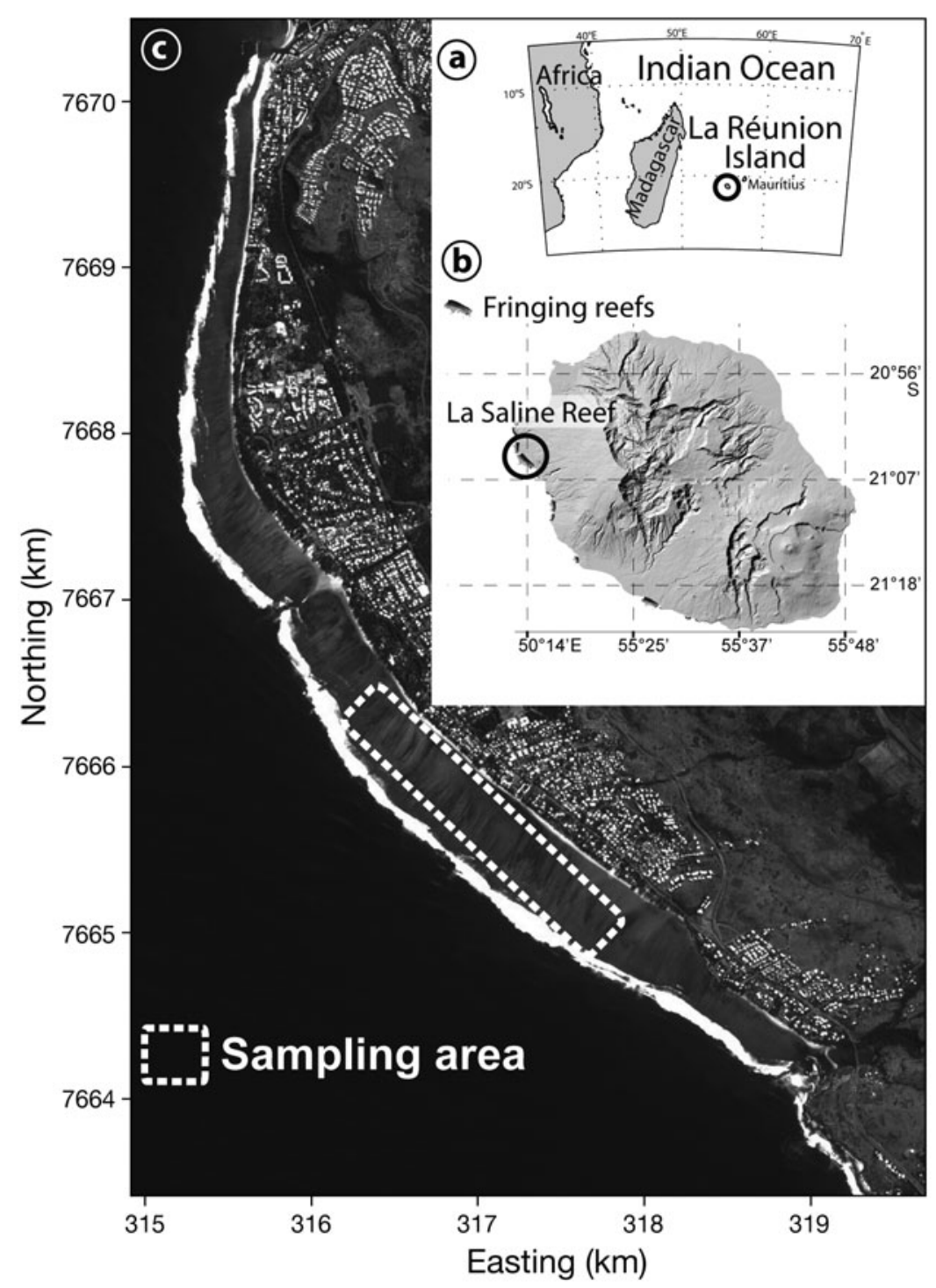

Fig. 1. La Saline reef, Réunion Island, southwestern Indian Ocean. Dashed rectangle indicates the sampling area

mesh size and spear guns. After collection, fish were placed in an ice bath, transported to the laboratory and frozen at $-20^{\circ} \mathrm{C}$. Size (TL), wet mass, sex and gonad weight were recorded for each individual before further analysis.

Particulate organic matter (POM) was used as a proxy for pelagic food sources and was obtained by filtering oceanic seawater (at 3 and $8 \mathrm{~km}$ from the coast) using $25 \mathrm{~mm}$ GF/C precombusted filters $\left(4 \mathrm{~h}\right.$ at $450^{\circ} \mathrm{C}$ ). Softbottom macrofauna (organisms $\geq 1 \mathrm{~mm}$ : annelids, arthropods and molluscs) were sampled using an air-lift system and used as an end member proxy of macrobenthic food sources. Although we found meiofauna prey items (organisms < $500 \mu \mathrm{m}$ ) in Mulloidichthys flavolineatus stomach contents, we could not exclude the presence of other microbenthic organisms (organisms $<45 \mu \mathrm{m}$ : bacteria, ciliates and microphytobenthos). Hence, we used reef sediment total organic matter (STOM) as a proxy of micro/meiobenthos food sources. All associated samples were obtained at the time of the fish sampling.

Stomach content analysis. Stomachs were removed, thawed, drained and treated as follows. Total mass of the content of each stomach was determined. Relative mass was calculated as stomach content wet mass divided by body wet mass, minus stomach content wet mass. Stomach contents were sorted into main prey categories and identifiable prey items were counted (see lines in Table 1). Due to the very small size of prey, the mean volume of each prey taxa was assessed from width and length of subsampled individuals, converted into basic geometric forms. Prey were identified to the lowest taxonomic level possible and assigned to one of 4 prey types: vegetal, micro-, meio- and macrofauna (see Table 1).

To characterize the diet composition of each fish size group, 3 dietary indices have been used for each identified prey item $i$ : frequency of occurrence in stomachs $\left(O_{i}=\right.$ number of stomachs including prey category $i$ divided by total number of non-empty stomachs), numerical importance $\left(N_{i}=\right.$ total number of prey category $i$ divided by total number of prey items) and volume ( $V_{i}=$ total volume of prey category $i$ divided by total volume of prey items). Sediment volume was also estimated since it comprised a significant proportion of most stomach contents.

Diet overlap between the size groups was assessed using the Morisita-Horn index (see Krebs 1998). This overlap index was calculated from abundance and volume data of prey categories identified at the family level, using the following formula:

$$
C_{m h}=\frac{2 \sum_{i=1}^{S} p_{A, i} \times p_{B, i}}{\sum_{i=1}^{S} p_{A, I}^{2}+\sum_{i=1}^{S} p_{B, I}^{2}}
$$

where $C_{m h}=$ Morisita-Horn index of overlap between predator A and $\mathrm{B}_{;} S=$ total number or volume of identified prey species in the feeding regime of both predators; $p_{A, i}=$ number or volume of individuals of prey species $i$ consumed by predator $A_{;}$and $p_{B, i}=$ number or 
volume of individuals of prey species $i$ consumed by predator B. $C_{m h}$ ranges from 0 (no prey in common) to 1 (complete overlap). A significant overlap is commonly assumed for index values greater than 0.6 (Zaret \& Rand 1971).

Stable isotope analyses. Dorsal white muscle tissue was sampled from individuals for carbon and nitrogen stable isotope analyses. To obtain STOM samples, detritus, macroalgae fragments and macrofauna were removed from sediment cores (top $2 \mathrm{~cm}$ of sediment, core $\varnothing=3.5 \mathrm{~cm})$ and were acidified $(1 \mathrm{~N} \mathrm{HCl})$ to eliminate inorganic carbon for $\delta^{13} \mathrm{C}$ measurements. Samples were freeze-dried and ground to a homogenous powder using an automated grinder. POM filters were pretreated and analyzed according to Lorrain et al. (2003). Macrofauna samples were analyzed following Kolasinski et al. (2008). Lipids were not removed as Mulloidichthys flavolineatus white muscle, macrofauna and STOM have a low lipid content ( $\mathrm{C} / \mathrm{N}$ ratio of all samples were $<4$ ), which does not affect $\delta^{13} \mathrm{C}$ values of these measurements (Post et al. 2007). Fish muscle $(1.5 \mathrm{mg})$, POM (whole filter), STOM (100 mg) and macrofauna (1.5 to $2.4 \mathrm{mg}$ ) samples were weighed into tin capsules and analyzed in duplicate.

Carbon and nitrogen content and isotopic composition were analyzed at the Stable Isotope Laboratory, GNS Science, New Zealand, using a Europa Geo 20/20 isotope ratio mass spectrometer (IRMS; PDZ Europa) interfaced to an ANCA-SL elemental analyzer (EA; PDZ Europa) in continuous flow mode (EAIRMS). Carbon dioxide and nitrogen gases were separated on a gas chromatography (GC) column at $68^{\circ} \mathrm{C}$ and analyzed for isotopic abundance. The ${ }^{13} \mathrm{C} /{ }^{12} \mathrm{C}$ and ${ }^{15} \mathrm{~N} /{ }^{14} \mathrm{~N}$ compositions are expressed in conventional delta notation in per mille (\%) relative to the levels of $\delta^{13} \mathrm{C}$ in Vienna Pee Dee Belemnite (VPDB) and $\delta^{15} \mathrm{~N}$ in atmospheric air, according to the following equation:

$$
\delta \mathrm{X}=\left[\left(\mathrm{R}_{\text {sample }} / \mathrm{R}_{\text {standard }}\right)-1\right] \times 1000
$$

where $\mathrm{X}$ is $\delta^{13} \mathrm{C}$ or $\delta^{15} \mathrm{~N}$ and $\mathrm{R}$ is the ratio of heavy to light isotope $\left({ }^{13} \mathrm{C} /{ }^{12} \mathrm{C}\right.$ or $\left.{ }^{15} \mathrm{~N} /{ }^{14} \mathrm{~N}\right)$. Repeated measurement of an internal standard exhibited a precision of $\pm 0.1 \%$ for $\delta^{13} \mathrm{C}$ and $\pm 0.3 \%$ for $\delta^{15} \mathrm{~N}$.

Data analysis. Mulloidichthys flavolineatus samples ranged from 9.3 to $24.9 \mathrm{~cm}$ TL $($ median $=11.7 \mathrm{~cm}$ ). Three groups were recognized based on length frequency modes and gonad development: juveniles $(<12 \mathrm{~cm} \mathrm{TL})$ newly recruited to the reef and presenting undifferentiated gonads, young adults $(12 \leq \mathrm{TL}<$ $17 \mathrm{~cm}$ ) which are both non-sexually and sexually differentiated, and adults $(\geq 17 \mathrm{~cm}$ TL) with sexually mature gonads. Multivariate analyses were performed on prey item volume for each size group to assess ontogenetic changes in yellowstripe goatfish diet. Data were log-transformed to minimize effects of dominant consumed items. A similarity matrix based on BrayCurtis coefficients was classified by hierarchical agglomerative clustering using the unweighted pair group mean arithmetic (UPGMA) linking method. All calculations and tests were performed with PRIMER 6.0 (Clarke \& Gorley 2006). Differences in feeding regime were tested using non-parametric procedures when data did not fulfill homoscedasticity requirements.

Sex effects on $\delta^{13} \mathrm{C}$ and $\delta^{15} \mathrm{~N}$ values were investigated within size groups using univariate analysis of covariance (ANCOVA) with TL as a covariate to take into account size effects on stable isotope values. $\delta^{13} \mathrm{C}$ and $\delta^{15} \mathrm{~N}$ values were analyzed separately to investigate size effects using regression models. Trophic level was calculated for each size group following Hobson \& Welch (1992):

$$
\text { Trophic level }=2.5+\left(\delta^{15} \mathrm{~N}_{\text {observed }}-7.5\right) / 2.3
$$

where the average macrofauna trophic level is 2.5 , $\delta^{15} \mathrm{~N}_{\text {observed }}$ is the $\delta^{15} \mathrm{~N}$ value of the yellowstripe goatfish, the average $\delta^{15} \mathrm{~N}$ value of the end member macrofauna is $7.5 \%$ and the $\delta^{15} \mathrm{~N}$ enrichment value per trophic level is $2.3 \%$. Post (2002) reported that $\delta^{15} \mathrm{~N}$ enrichment can range from 2 to $5 \%$ in aquatic ecosystems. Since fractionation values are undetermined for Mulloidichthys flavolineatus, the trophic fractionation of $2.3 \%$ (McCutchan et al. 2003) represents a mean value for aquatic organims feeding on either high (animal, microbial) or low (algal) protein content diets.

A 3-source isotope mixing model (Phillips \& Gregg 2003) was used to estimate the proportional contributions of pelagic, micro/meiobenthic and macrobenthic food sources to the diets of juveniles and young adults. Pelagic, micro/meiobenthic and macrobenthic sources are the average isotopic signatures of POM, STOM and macrofauna, respectively. Trophic enrichment factors of 2.3 and $0.5 \%$ were used for $\delta^{15} \mathrm{~N}$ and $\delta^{13} \mathrm{C}$, respectively. A von Bertalanffy model for the growth rates of Mulloidichthys flavolineatus (Holland et al. 1993) indicated that minimum size of juveniles $(8.7 \mathrm{~cm} \mathrm{TL})$, young adults $(12 \mathrm{~cm} \mathrm{TL})$ and adults $(17 \mathrm{~cm} \mathrm{TL})$ corresponded to ages of around 10, 12 and $18 \mathrm{mo}$, respectively. Hence, a 2-source mixing model was used to investigate the respective contribution of micro/meiobenthic and macrobenthic food sources to the diet of adults since we assume that pelagic carbon and nitrogen have been totally replaced by a corresponding benthic signature in muscle tissue around 8 mo after settlement inside the reef environment. The 2-source isotope mixing model (Fry 2006) was calculated with a trophic enrichement factor $(I)$ of $0.5 \%$ : 


$$
\begin{aligned}
& \% \text { macrobenthic }= \\
& 100 \times \frac{\left(\delta^{13} \mathrm{C}_{\text {observed }}-\delta^{13} \mathrm{C}_{\text {micro/meiobenthic }}-I\right)}{\left(\delta^{13} \mathrm{C}_{\text {macrobenthic }}-\delta^{13} \mathrm{C}_{\text {micro/meiobenthic }}\right)}
\end{aligned}
$$

and $\%$ micro/meiobenthic $=100-\%$ macrobenthic. The mixing model calculates all feasible combinations of sources that could explain the consumer isotope value, thereby placing limits on the dietary contributions of each source. Various diet contributions were tested using ANCOVA with TL as a covariate.

\section{RESULTS}

\section{Stomach content analysis}

\section{Overall diet}

We analyzed stomach contents of 110 yellowstripe goatfish. No empty stomachs were found. Average volume of the juvenile's stomach content $(\mathrm{n}=64)$ was $55.7 \mathrm{~mm}^{3}$ (ranging from $<0.1$ to $207.1 \mathrm{~mm}^{3}$ ). The diet of juveniles was dominated by annelids and arthropods (56.0 and $36.6 \%$ of volume, respectively), while nematodes contributed only a minor part (5.7\% of volume) (Table 1). Stomach content volume in young adults $(\mathrm{n}=$ 26) was on average $154.0 \mathrm{~mm}^{3}$ (ranging from 10.9 to $316.2 \mathrm{~mm}^{3}$ ). Annelids were the most important food source for this group (70.9\% of volume), while arthropods ranked second $(22.5 \%)$ and echinoderms and nematodes represented 2.4 and $2.3 \%$, respectively, of total volume. The average stomach content volume of the 20 adults studied was $146.8 \mathrm{~mm}^{3}$ (ranging from 0.5 to $332.5 \mathrm{~mm}^{3}$ ). Annelids were the most important food source for adults (annelids: $52.1 \%$; arthropods: $38.7 \%$; echinoderms: $6.5 \%$ of volume). On the basis of prey number, the trend differed since arthropods were the most common food source in adults (55.8\%) and juveniles $(47.5 \%)$ diets, but ranked second for young adults $(44.7 \%)$. Nematodes were most common for juveniles (46.7\% by number) and young adults (47.4\%), and decreased in adults $(31.0 \%)$. The contribution of polychaetes to the Mulloidichthys flavolineatus diet was low for all size groups, increasing from $1.7 \%$ for juveniles to 3.1 and $3.6 \%$ for adults and young adults, respectively.

Sediment occurred in stomachs more frequently in young adults and adults (88 and $90 \%$ of individuals, respectively) than in juveniles (11\%). Differences in sediment occurrence in stomach contents was significant between juveniles and adults $\left(\chi^{2}=41.86, \mathrm{p}<0.01\right)$ and between juveniles and young adults $\left(\chi^{2}=46.58\right.$, $\mathrm{p}<0.01)$, but not between adults and young adults $\left(\chi^{2}=0.10, p=0.76\right)$. Sediment proportion in each stomach content's total volume decreased from young adults (mean of $19.0 \%$ ) to adults $(11.8 \%$ ) and juveniles $(0.5 \%)$. Differences in ingested sediment volume was significant between juveniles and both young adults (Mann-Whitney test: $Z=7.59, \mathrm{p}<0.01)$ and adults $(Z=$ 7.12, p < 0.01); no difference was observed between adults and young adults $(Z=1.73, \mathrm{p}=0.083)$.

\section{Prey taxonomic analysis}

Juveniles. Ten prey families and 8994 prey items were found in stomachs of the 64 juveniles sampled (Table 1$)$, with a mean $( \pm$ SE) of $140.5 \pm 31.8$ prey items per stomach. Malacostracans were the dominant prey, followed by Adenophoera nematodes and polychaetes. Major food items were harpacticoid copepods (37.1\% by number, $27.3 \%$ by volume), tanaids of the Leptocheliidae family $(10.4 \%$ by number, $9.3 \%$ by volume) and nematodes of the Chromadoridae family ( $46.7 \%$ by number, $5.7 \%$ by volume). In total, these prey contributed 94.2 and $42.3 \%$ by number and volume, respectively. Despite the low number of polychaetes $(1.7 \%)$, they were the dominant prey by volume $(56.0 \%)$. We note that foraminifera of the Miliolidae and Amphisteginidae families occurred frequently in stomach contents (48.4 and 64.1\%, respectively) although their abundance and volume were low. Naticidae occured in $26.6 \%$ of stomach contents and was the unique gastropod family consumed by juveniles.

Young adults. Seventeen prey families and 4040 prey items were found in the stomachs of the 26 young adults sampled (Table 1$)$, with a mean $( \pm \mathrm{SE})$ of $155.4 \pm$ 37.6 prey items per stomach. Malacostracans occured in 25 samples (96.2\%) and contributed $44.7 \%$ by number and $22.5 \%$ by volume. Harpacticoid copepods and tanaids of the Leptocheliidae family were the main malacostracan components; together they represented $43.2 \%$ of the diet by number and $21.3 \%$ by volume. Other malacostracan prey included amphipods of the Melitidae family (observed in $46.2 \%$ of the stomachs) and some undetermined decapods and isopods. Nematodes of the Chromadoridae family dominated the young adult's diet ( $47.4 \%$ by number) but, owing to their small size, only represented $2.3 \%$ of the diet by volume. Polychaetes did not contribute significantly to the total number of prey $(3.6 \%)$ but they constituted the main prey item by volume $(70.9 \%)$. Gastropods (Nassariidae, Cypraeidae and Naticidae) were also present in the diet; Naticidae were found in $42.3 \%$ of the stomachs.

Adults. A total of 2706 prey items belonging to 16 families were recorded in the stomachs of the 20 adults sampled (Table 1), with a mean $( \pm \mathrm{SE})$ of $135.3 \pm 49.5$ prey items per stomach. Malacostracans occurred in 


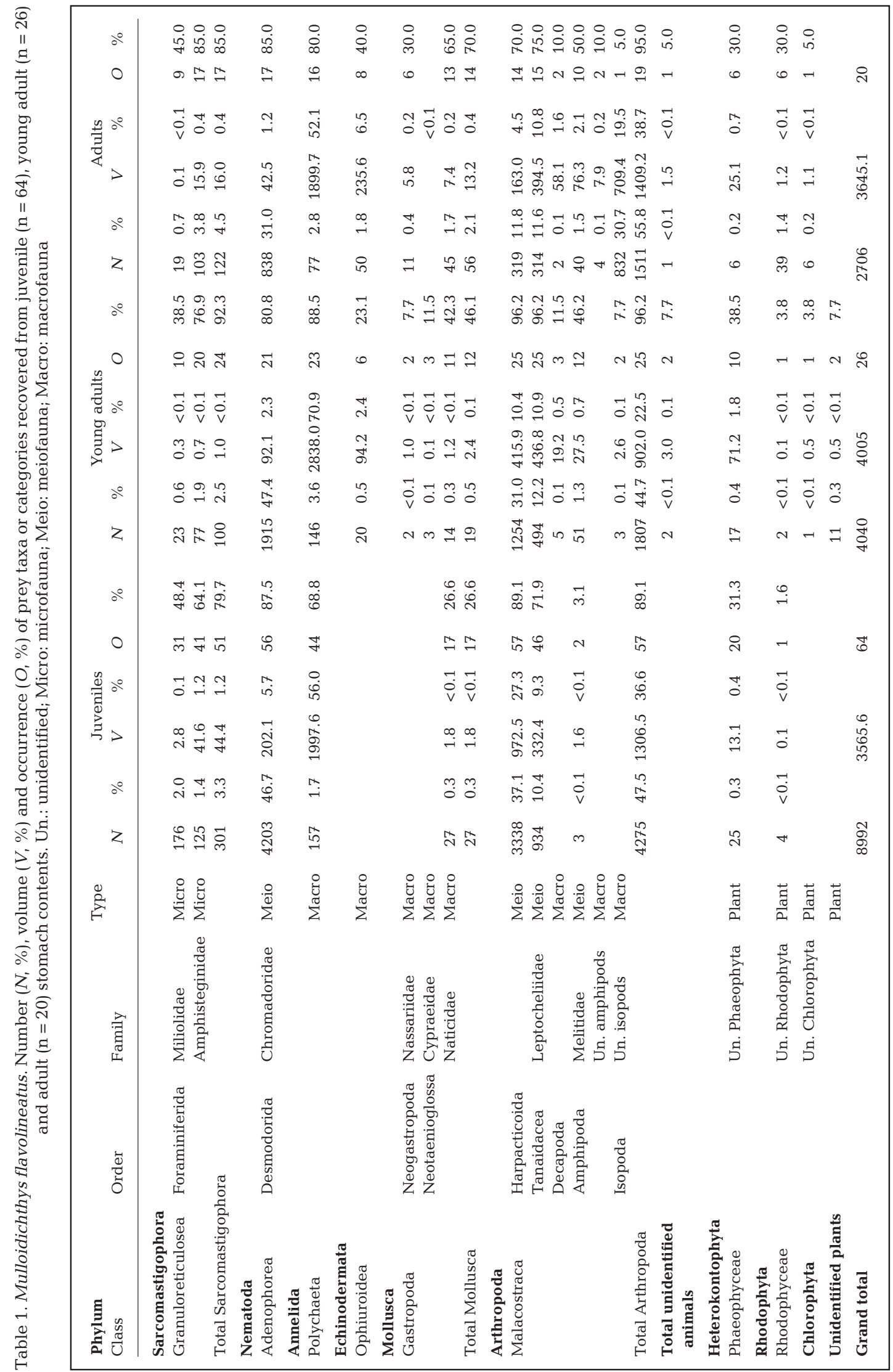


$95 \%$ of stomachs; they dominated the diet by number $(55.8 \%)$ and ranked second by volume $(38.7 \%)$. Isopods $(30.5 \%$ by number, $19.5 \%$ by volume) and tanaids of the Leptocheliidae family $(11.6 \%$ by number, $10.8 \%$ by volume) were the dominant malacostracan prey. Among other malacostracan families, harpacticoid copepods and Melitidae had the highest occurrence ( 70 and $50 \%$, respectively), and polychaetes ranked first by volume $(52.1 \%)$. Nematodes of the Chromadoridae family occurred in $85 \%$ of the stomachs, and they contributed $31.0 \%$ to diet by number but only $1.2 \%$ by volume. Amphisteginidae foraminifers were observed in $85 \%$ of stomachs but their contribution to diet by number $(3.8 \%)$ and volume $(0.4 \%)$ were low. Gastropod prey were represented by Nassariidae (40\% occurrence) and Naticidae (60\% occurrence), but their diet contribution was negligible ( 0.4 and $1.7 \%$ by number, respectively, $0.2 \%$ each by volume).

\section{Comparison of feeding regimes}

Differences in prey number were significant between juveniles (mean of $4.9 \pm 1.9$ ) and both young adults $(6.9 \pm 2.0)$ and adults $(7.2 \pm 2.7$; Mann-Whitney: $Z=3.98, \mathrm{p}<0.01$ and $Z=3.48, \mathrm{p}<0.01$, respectively). No significant differences were observed between young adults and adults $(Z=0.81, \mathrm{p}=$ 0.426). The effect of fish size on prey number was not significant (Kruskal-Wallis: $H=1.58, \mathrm{p}=0.451$ ); however, a significant size effect was observed for both total volume $(H=26.90, \mathrm{p}<0.01)$ and relative mass $(H=20.14, \mathrm{p}<0.01)$. For each pairing of size groups, Morisita-Horn index values calculated both on number and volume of prey items were >0.6 (Table 2), indicating a strong overlap between the different size groups. Juveniles and young adults had the highest overlap indices among all size-group pairs (0.993 based on prey number and 0.943 based on prey volume). Fish pairs containing the young adult group presented the highest index values. Diet analysis based on volume (Table 1) indicated that Mulloid-

Table 2. Mulloidichthys flavolineatus. Morisita-Horn overlap index of dietary composition based upon number of prey items (values in italics) and volume (values in bold) for each size group

\begin{tabular}{|lccc|}
\hline Size group & Juveniles & Young adults & Adults \\
\hline Juveniles & & 0.993 & 0.685 \\
Young adults & $\mathbf{0 . 9 4 3}$ & & 0.715 \\
Adults & $\mathbf{0 . 8 6 5}$ & $\mathbf{0 . 9 0 8}$ & \\
\hline
\end{tabular}

ichthys flavolineatus gradually shifted to a mixed meio-/macrofauna diet in juveniles (43.5 and 56.1\% of prey total volume, respectively) to a macrofaunadominated diet in young adults $(24.3 \%$ for meiofauna, $74.2 \%$ for macrofauna) and adults (19 and $80.4 \%$ ). Moreover, clusters calculated from prey volumes showed that all groups shared 3 common prey taxa: polychaetes (macrofauna), and Leptocheliidae tanaids and harpacticoid copepods (meiofauna) (Fig. 2). Together, these prey dominated the diet by volume $(92.6 \%$ of total prey volume in juveniles, $95.8 \%$ in young adults and $67.4 \%$ in adults) (Table 1 ). In juvenile and young adult diets, meiofauna taxa were added to the common prey pool: Chromadoridae nematodes in both groups, Amphisteginidae foraminifers in juveniles (Fig. 2a) and Melitidae amphipods in young adults (Fig. 2b). Melitidae amphipods were maintained into the common prey pool in adult group and macrofauna taxa (ophiuroids) were added (Fig. 2c). Surprisingly, phaeophyta had a noticeable presence in stomach contents (from 30.0 to $38.5 \%$ of occurrence) (Table 1).

\section{Stable isotope analysis}

A total of 103 muscle samples of Mulloidichthys flavolineatus were analyzed for stable isotopes $\left(\delta^{13} \mathrm{C}\right.$ and $\delta^{15} \mathrm{~N}$ ). Mean values for each size group are presented in Table 3. There were significant variations in $\delta^{13} \mathrm{C}$ and $\delta^{15} \mathrm{~N}$ values among size groups (ANCOVA: $\left.\delta^{13} \mathrm{C}, F=12.81, \mathrm{p}<0.001 ; \delta^{15} \mathrm{~N}, F=9.14, \mathrm{p}<0.001\right)$. Newman-Keuls post hoc tests revealed differences in $\delta^{13} \mathrm{C}$ values between juveniles (mean $\delta^{13} \mathrm{C}$ of $-17.1 \pm$ $0.5 \%)$, young adults $(-14.1 \pm 2.3 \%$ o) and adults $(-10.7 \pm$ $0.8 \%$ ). For $\delta^{15} \mathrm{~N}$, significant differences were observed between adults (mean $\delta^{15} \mathrm{~N}: 11.1 \pm 1.8 \%$ ) and the 2 smaller size groups (juveniles and young adults, mean $\delta^{15} \mathrm{~N}$ of $7.7 \pm 0.5$ and $7.4 \pm 0.5 \%$, respectively). There were significant differences in the $\delta^{13} \mathrm{C}$ values of young adults with undifferentiated gonads (mean of $-15.2 \pm 2.2 \%$ ) and sexually differentiated young adults $(-13.8 \pm 0.8 \%$; $F=21.32, \mathrm{p}<0.001)$. There were no significant differences in $\delta^{13} \mathrm{C}$ values between male and female young adults (Kruskal-Wallis: $H=0.22, \mathrm{p}=$ 0.638). No significant sex effects were observed in $\delta^{13} \mathrm{C}$ values of adults $(F=2.32, \mathrm{p}=0.115)$, nor in $\delta^{15} \mathrm{~N}$ values of both young adults and adults $(F=1.93, \mathrm{p}=0.155$ and $F=1.08, \mathrm{p}=0.385$, respectively).

\section{$\delta^{13} \mathrm{C}$ isotopes}

$\delta^{13} \mathrm{C}$ values of juveniles ranged from -17.6 to $-14.3 \%$ (Fig. 3a). A slight increase in $\delta^{13} \mathrm{C}$ values with TL was 

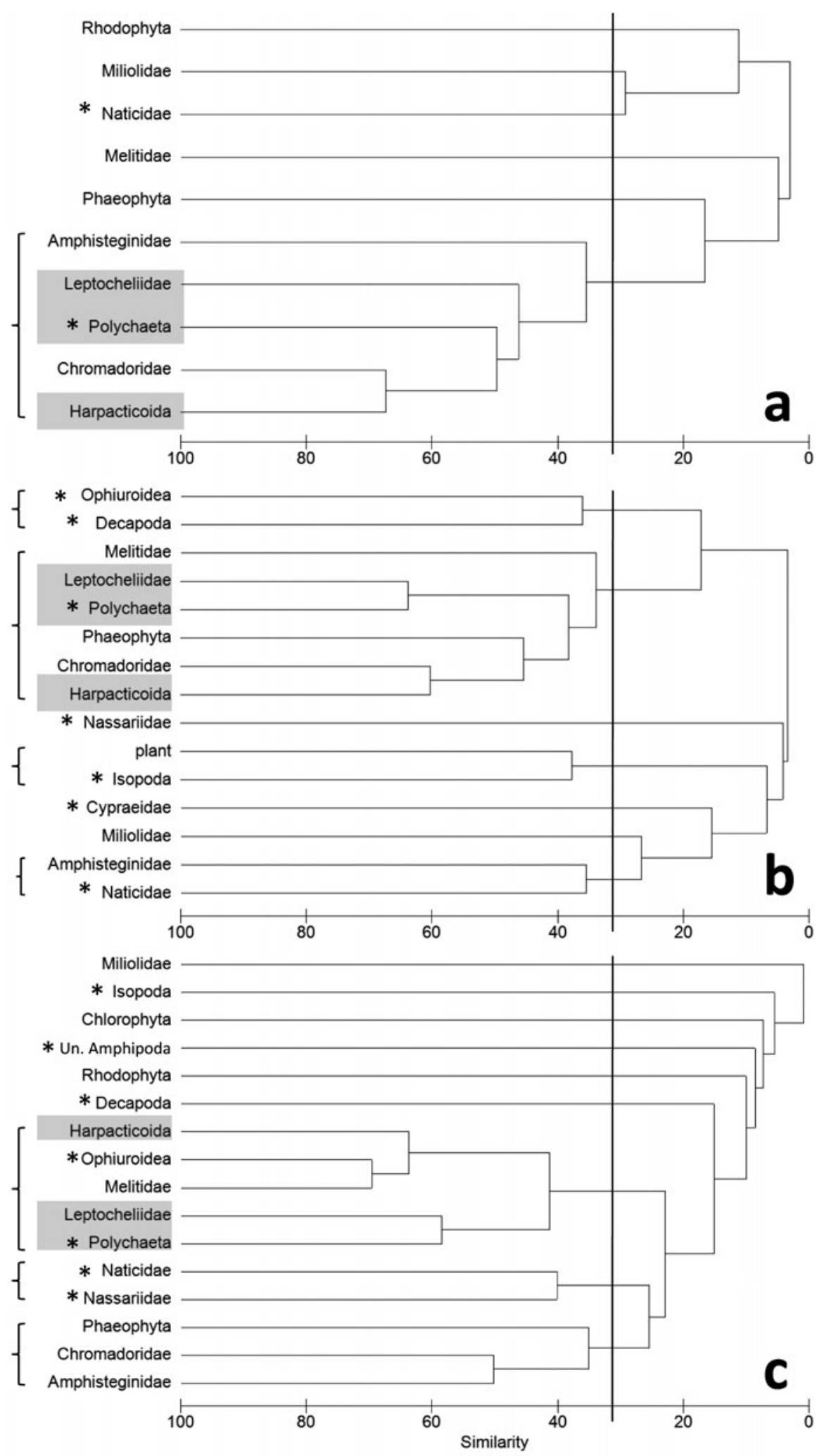

Fig. 2. Mulloidichthys flavolineatus. Hierarchical cluster analysis of stomach contents based on a Bray-Curtis similarity matrix of prey taxa volume, performed for each size group: (a) juveniles, (b) young adults and (c) adults. Vertical bars indicate the similarity level (\%) selected to define groups. Grey areas illustrate the common pool of prey taxa which dominated the diet by volume. Asterisks distinguish macrofauna taxa from micro- and meiofauna taxa (no asterisks). Un.: unidentified 
Table 3. Mulloidichthys flavolineatus. Mean $( \pm \mathrm{SD})$ and range of carbon and nitrogen stable isotope values and trophic level estimation of each size group. $\mathrm{TL}=$ total length, $\mathrm{n}=$ number of samples

\begin{tabular}{|lcccc|}
\hline Size group & $\begin{array}{c}\text { Stable } \\
\text { isotope }\end{array}$ & $\begin{array}{c}\text { Mean } \\
(\%)\end{array}$ & $\begin{array}{c}\text { Range } \\
(\% \circ)\end{array}$ & $\begin{array}{c}\text { Trophic } \\
\text { level }\end{array}$ \\
\hline Juveniles & $\delta^{13} \mathrm{C}$ & $-17.1 \pm 0.5$ & $-17.6:-14.3$ & \\
$<12 \mathrm{~cm}$ TL $(\mathrm{n}=59)$ & $\delta^{15} \mathrm{~N}$ & $7.7 \pm 0.5$ & $6.7: 8.7$ & $2.6 \pm 0.2$ \\
Young adults & $\delta^{13} \mathrm{C}$ & $-14.1 \pm 2.3$ & $-17.6:-11.2$ & \\
$12 \leq \mathrm{TL}<17 \mathrm{~cm}(\mathrm{n}=26)$ & $\delta^{15} \mathrm{~N}$ & $7.4 \pm 0.5$ & $7.1: 8.8$ & $2.5 \pm 0.1$ \\
Adults & $\delta^{13} \mathrm{C}$ & $-10.7 \pm 0.8$ & $-12.3:-9.5$ & \\
$\geq 17 \mathrm{~cm}$ TL $(\mathrm{n}=18)$ & $\delta^{15} \mathrm{~N}$ & $11.1 \pm 1.8$ & $7.3: 12.9$ & $3.8 \pm 0.7$ \\
\hline
\end{tabular}

observed (Fig. 3b) for juveniles $\left(\delta^{13} \mathrm{C}_{\mathrm{ju}}\right.$ veniles $=0.37 \mathrm{TL}-21.20 ; \mathrm{R}^{2}=0.064, \mathrm{n}=$ $59, \mathrm{p}=0.030)$. The range of $\delta^{13} \mathrm{C}$ values was greater for young adults $(-17.6$ to $-11.2 \%)$ than for juveniles or adults, and increased rapidly as a function of TL $\left(\delta^{13} \mathrm{C}_{\text {young-adults }}=1.40 \mathrm{TL}\right.$ $\left.-32.99 ; \mathrm{R}^{2}=0.736, \mathrm{n}=26, \mathrm{p}<0.001\right)$. $\delta^{13} \mathrm{C}$ values of adults ranged from -12.3 to $-9.5 \%$, but were not significantly correlated with TL $\left(\delta^{13} \mathrm{C}_{\text {adults }}=\right.$ $0.19 \mathrm{TL}-14.71 ; \mathrm{R}^{2}=0.079, \mathrm{n}=18, \mathrm{p}=$ 0.128). Hence, a logistic regression between $\delta^{13} \mathrm{C}$ values and TL was modelled for Mulloidichthys flavolineatus (Fig. 3a): $\delta^{13} \mathrm{C}_{\text {yellowstripe goatfish }}=-6.32 /[1+$ $\left.(\mathrm{TL} / 12.98)^{26.27}\right]-11.00 ; \mathrm{R}^{2}=0.928, \mathrm{n}=103, \mathrm{p}<0.001$.

\section{$\delta^{15} \mathrm{~N}$ isotopes}

$\delta^{15} \mathrm{~N}$ values of juvenile fish ranged from 6.7 to $8.7 \%$, and were not correlated with TL $\left(\delta^{15} \mathrm{~N}_{\text {juveniles }}=0.16 \mathrm{TL}+\right.$ $5.94 ; \mathrm{R}^{2}=0.002, \mathrm{n}=59, \mathrm{p}=0.299$ ). For young adults, $\delta^{15} \mathrm{~N}$ values ranged from 7.1 to $8.8 \%$, decreasing slightly with size $\left(\delta^{15} \mathrm{~N}_{\text {young-adults }}=-0.20 \mathrm{TL}+10.21 ; \mathrm{R}^{2}=\right.$ $0.181, \mathrm{n}=26, \mathrm{p}=0.019$ ) (Fig. $3 \mathrm{c}$ ). $\delta^{15} \mathrm{~N}$ values of adults varied highly among individuals and ranged from 7.3 to $12.9 \%$. Two groups of individuals were identified (Fig. 3) with mean $\delta^{15} \mathrm{~N}$ values of $11.9 \pm 0.8$ and $7.8 \pm$ $0.6 \%$ (Mann-Whitney: $Z=3.27, \mathrm{p}<0.01) . \delta^{15} \mathrm{~N}$ values of adults were not correlated with TL $\left(\delta^{15} \mathrm{~N}_{\text {adults }}=\right.$ $\left.0.23 T L+6.27 ; R^{2}=-0.003, n=18, p=0.344\right)$. There was a difference of one trophic level between adults (mean trophic level of $3.8 \pm 0.7$ ) and young adults and juveniles $(2.5 \pm 0.1$ and $2.6 \pm 0.2$, respectively; KruskalWallis: $H=30.44, \mathrm{p}<0.001$ ) (Table 3 ). As $\delta^{15} \mathrm{~N}$ values greatly varied within each group (up to 1 trophic level in adult group), data were not fitted using a model approach.

\section{Food source contribution to diet}

The average $\delta^{13} \mathrm{C}$ and $\delta^{15} \mathrm{~N}$ values of pelagic POM were $-22.5 \pm 0.5$ and $4.4 \pm 0.2 \%$, respectively. STOM, the proxy for micro-/meiobenthos food sources, had average $\delta^{13} \mathrm{C}$ values of $-16.0 \pm 0.9 \%$ and $\delta^{15} \mathrm{~N}$ values of $3.3 \pm 0.3 \%$. Macrofauna was the most enriched food source with mean $\delta^{13} \mathrm{C}$ and $\delta^{15} \mathrm{~N}$ values of $-11.9 \pm 1.3$ and $7.5 \pm 1.4 \%$, respectively (Fig. 4). Results of isotope mixing models are presented in Fig. 5. Contribution of pelagic food sources to overall diet decreased significantly (ANCOVA: $F=84.3, \mathrm{p}<0.01$ ) from juveniles (mean of $47.7 \%$ ) to young adults $(17.0 \%$ ), concurrent
Fig. 3. Mulloidichthys flavolineatus. (a) $\delta^{13} \mathrm{C}$ and (c) $\delta^{15} \mathrm{~N}$ values of $M$. flavolineatus as a function of total length (TL; $\mathrm{n}=$ 103). Symbols represent size groups: juveniles $(n=59)$, young adults $(\mathrm{n}=26)$ and adults $(\mathrm{n}=18)$. (a) A logistic model was fitted to $\delta^{13} \mathrm{C}$ data (solid line; $\delta^{13} \mathrm{C}=-6.32 /\left[1+(\mathrm{TL} / 12.98)^{26.27}\right]-$ $11.00, \mathrm{R}^{2}=0.928, \mathrm{p}<0.001$ ). (b) A linear regression model was fitted to juvenile $\delta^{13} \mathrm{C}$ values (solid line; $\delta^{13} \mathrm{C}=0.37 \mathrm{TL}-21.20$; $\left.\mathrm{R}^{2}=0.064, \mathrm{p}=0.030\right)$ 


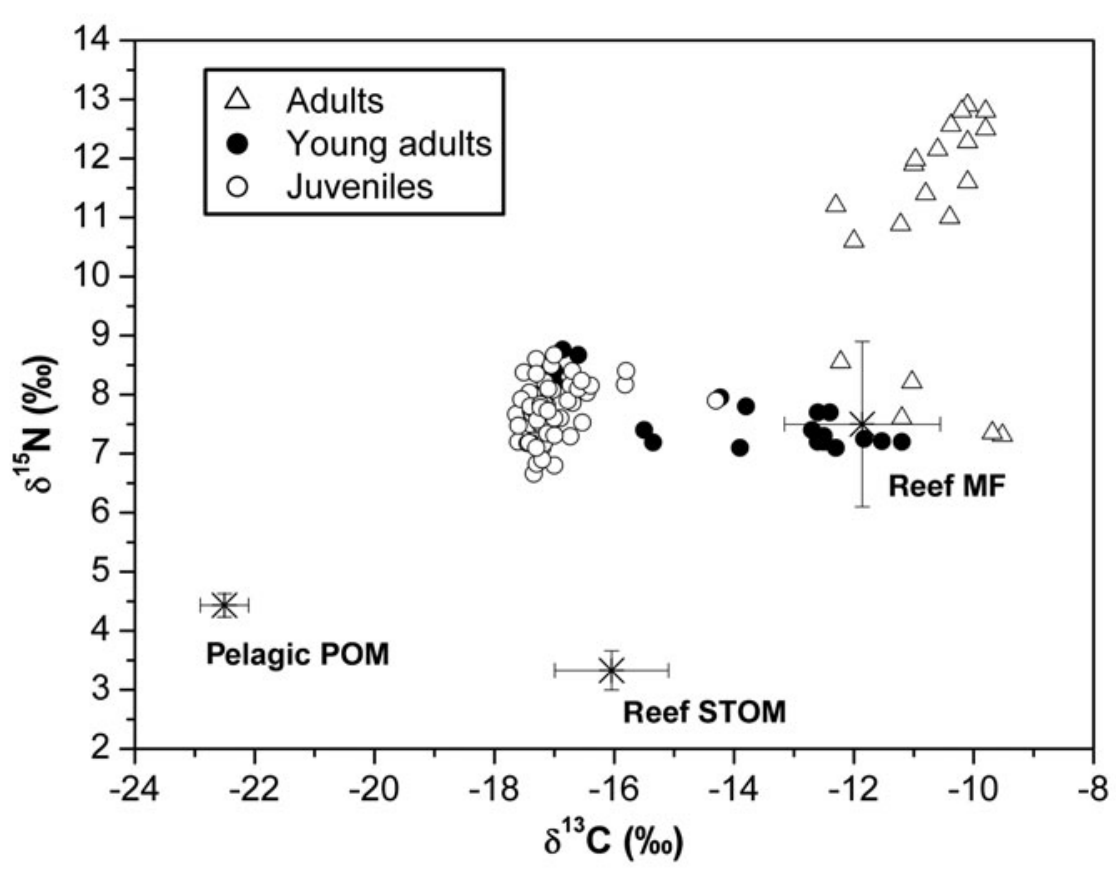

Fig. 4. Mulloidichthys flavolineatus. Mean $( \pm \mathrm{SD}) \delta^{13} \mathrm{C}$ and $\delta^{15} \mathrm{~N}$ values of $M$. flavolineatus and potential food sources. Symbols represent size groups: juveniles $(\mathrm{n}=59)$, young adults $(\mathrm{n}=26)$ and adults $(\mathrm{n}=18) . \delta^{13} \mathrm{C}$ and $\delta^{15} \mathrm{~N}$ signatures of pelagic particulate organic matter $(\mathrm{POM} \mathrm{n}=9)$, reef sediment total organic matter $(\mathrm{STOM} ; \mathrm{n}=15)$ and reef macrofauna (MF; annelids, $\mathrm{n}=31$; arthropods, $\mathrm{n}=24$; molluscs, $\mathrm{n}=27$ ) are also shown

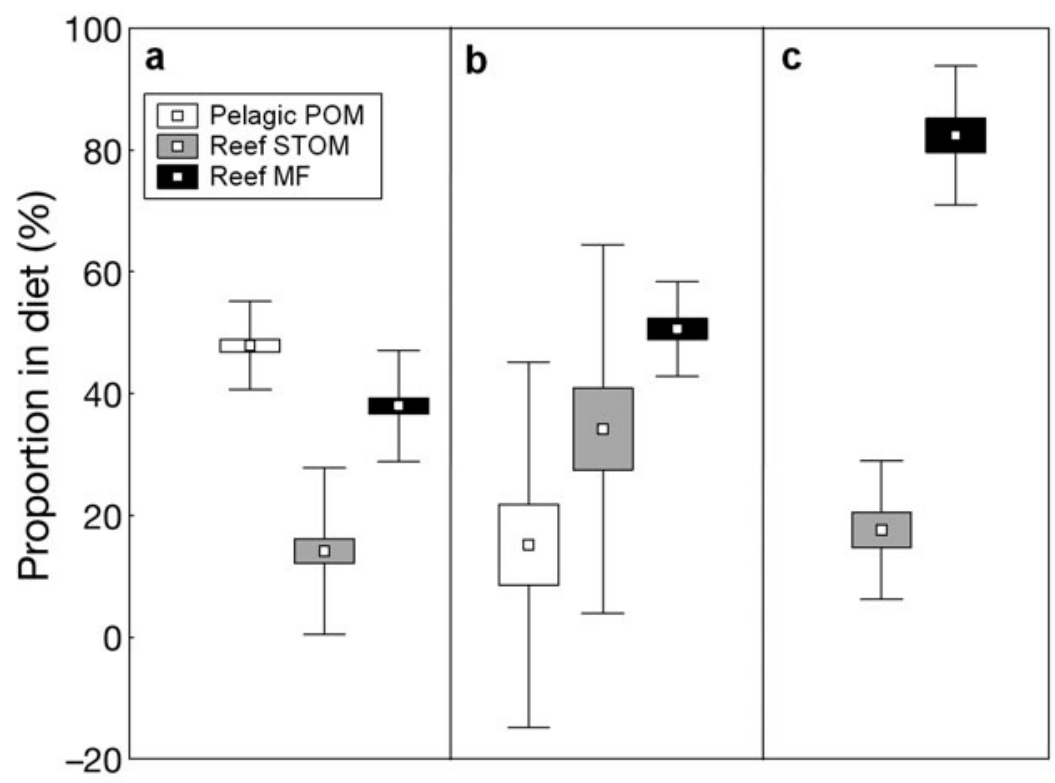

Fig. 5. Relative contribution (\%) of pelagic (pelagic POM), micro-/meiobenthic (reef STOM) and macrobenthic (reef MF) food sources to (a) juvenile, (b) young adult and (c) adult Mulloidichthys flavolineatus diet estimated by 3 - and 2-source isotopic mixing models. Boxes are means $\pm \mathrm{SE}$, errorbars are $\pm \mathrm{SD}$ to an increasing contribution of benthic sources. Micro-/meiobenthos food source contribution significantly increased from juveniles (mean of $14.6 \%$ ) to young adults $(32.3 \%)$, and decreased from young adults to adults $(17.6 \%, F=$ 24.0, p < 0.01). Macrobenthic food source contribution increased as a function of fish size $(F=16.2, \mathrm{p}<0.001)$ from juveniles $(37.7 \%)$ to young adults $(50.6 \%)$ and adults $(82.4 \%)$. Finally, young adults displayed a larger individual variability (see SD bars in Fig. 5) than adults and juveniles.

\section{DISCUSSION}

\section{Stomach content analysis}

Stomach content analysis reveals that the diet of Mulloidichthys flavolineatus from Reunion Island is predominantly composed of arthropods, nematodes and polychaetes. This result supports others findings for mullid fish (Ben-Eliahu \& Golani 1990, Golani \& Galil 1991, Wahbeh 1992, Platell et al. 1998, Lukoschek \& McCormick 2001) and more generally reflects the diet of most coral reef benthic carnivorous fish (Kulbicki et al. 2005). Arthropods and nematodes dominated the yellowstripe goatfish diet in La Saline reef in terms of frequency of occurrence and numerical abundance, but constituted a low biomass proportion of the diet due to the small sizes of these prey types. The opposite pattern was observed for polychaetes, which constituted the most important part of stomach content volume. Their low abundance in stomachs contrasts with their high densities in La Saline reef flat sediments compared to other taxa (Taddei 2006). This suggests that $M$. flavolineatus selects specific polychaetes for their diet. Such selectivity has been already highlighted by Sorden (1982), who observed M. flavolineatus to select against small, abundant polychaete species in the Midway Islands (Hawaii).

Except for nematodes, our results differ from a study of Mulloidichthys flavolineatus diet in the Gulf of Aqaba 
(Wahbeh 1992), where fish eggs, nematodes and molluscs dominated based on abundance, occurrence and gravimetric indices. In the present study, fish eggs were not observed and molluscs did not feature significantly in the feeding regime. However, specimens of M. flavolineatus from the Gulf of Aqaba were sampled in seagrass-rich areas, well known to host spawning aggregations (Moltschaniwskyj \& Pecl 2003) and rich mollusc communities (Baron et al. 1993), while seagrass beds at La Saline reef are small and sparse. Considerable variation in diet composition has been reported between mullid species (Golani \& Galil 1991, Platell et al. 1998), as well as within the same species from different locations (Lukoschek \& McCormick 2001). These differences in prey selection may be related to differences in availability of prey taxa at these locations and seasonal variability.

The diet of juvenile yellowstripe goatfish was numerically dominated by nematodes and harpacticoid copepods. Several demersal juvenile fish species have been found to feed primarily on these 2 taxa, providing evidence of the crucial role of meiofauna in supporting juvenile growth (Coull 1999). Ontogenetic diet changes in yellowstripe goatfish were demonstrated from diet analyses across the 3 size groups investigated and correspond to a widening of the prey spectrum with increasing size. Differences in diet composition observed between juveniles and adults consisted of a decrease in meiofauna (nematodes, tanaids and harpacticoid copepods) and microfauna (foraminifera) prey, concurrent with an increase in macrofauna prey (gastropods, echinoderms, isopods and decapods) from a common prey pool (polychaetes, tanaids [Leptocheliidae] and harpacticoid copepods). This is consistent with the conceptual model of a relationship between fish size and the size, biomass and diversity of prey (Scotto di Carlo et al. 1982, Harmelin-Vivien et al. 1989), limiting intraspecific competition for similarly sized prey (Huss et al. 2008). Intraspecific competition within fish cohorts, in particular following recruitment when juvenile density can affect resource density (Byström \& Garcia-Berthou 1999), was found to have a large influence on the inter-individual variation in resource use (Svanbäck \& Persson 2004). Size of the feeding apparatus, in particular the pharyngeal gape, has been associated with the size range of exploitable prey items (McCormick 1998). However, pharyngeal gape size was not the dominant factor in prey choice of Parupeneus barberinus (Lukoschek \& McCormick 2001). Changes in diet composition associated with increasing size of Mulloidichthys flavolineatus from La Saline reef concur with an increase in sediment ingestion. Sediment was also found to be a significant component of stomach contents of the same species from the Red Sea (Wahbeh 1992). In the present study, young adults and adults ingested sediment more frequently and in larger proportions than juveniles. These observations may be related to an ontogenetic change in foraging behaviour or change in microhabitat preference. Even though there is no data on foraging substrata used by $M$. flavolineatus, it is likely that juveniles concentrate their feeding efforts on prey associated with surface sediments or algal turfs, as stomachs contain a noticeable presence of fragments from algal mats, known to host a high abundance of invertebrates (Vetter 1994), while larger individuals forage deeper into the soft substrates. This has also been observed for some other mullid species (Eggold \& Motta 1992, Lukoschek \& McCormick 2001), associated with morphological modifications of specialized organs such as barbel development or elongation of the preorbital region of the head (Gosline 1984). The high values of the Morisita-Horn index, in particular between juveniles and young adults, attest to a high dietary overlap between successive size groups. This is due to the restricted group of prey they share which dominates the diet of each size group. The highest values of dietary overlap were observed for juvenileyoung adult and young adult-adult pairs, indicating that young adults are a transient group. Such findings reflect a gradual expansion of the trophic niche of the M. flavolineatus with increasing size. However, stomach content analysis cannot resolve questions pertaining to the temporal dynamics of such dietary changes.

\section{Stable isotope analyses}

Interpreting intraspecific stable isotope variations with body size as evidence of ontogenetic diet changes requires underlying assumptions, which can result in ambiguous conclusions if ignored (Gannes et al. 1997). In particular, isotopic fractionation may be the result of both diet shifts as well as changes in tissue turnover rates during ontogeny. Tissue turnover rate is a function of growth and metabolism (Fry \& Arnold 1982); fast-growing organisms have more rapid turnover rates and therefore more rapid isotope value changes (Hesslein et al. 1993). Despite the lack of information on fractionation rates in Mulloidichthys flavolineatus, we did not find any important changes in carbon isotopic composition according to size within the juvenile group, which experiences the greatest growth rate (Holland et al. 1993). Evidence from other teleosts (Fry 1983, Herzka \& Holt 2000) indicate that metabolic processes have little or no effect on isotopic composition. This implies that patterns of isotopic changes are mostly the result of a dilution of the initial isotopic pool by addition of newly deposited biomass. Hence, major observed modifications in tissue carbon isotopic com- 
position can be attributed to diet changes. The slight increase in $\delta^{13} \mathrm{C}$ values with size observed in juveniles could be attributed to a group of individuals that have settled earlier in the shallow reef flat, thus reflecting the effects of a benthic signal integrated over a longer time period.

Carbon isotopes are often used to trace energy pathways within a system because pelagic carbon is depleted in ${ }^{13} \mathrm{C}$ relative to carbon derived from bentholittoral sources (France 1995). Correlations between $\delta^{13} \mathrm{C}$ values and Mulloidichthys flavolineatus TL clearly demonstrate important intraspecific $\delta^{13} \mathrm{C}$ changes during ontogeny, consistent with other studies that have investigated ontogenetic diet shifts from juvenile to adult fish (Cocheret de la Morinière et al. 2003, Wells et al. 2008). In the La Saline reef, new recruits retained an offshore pelagic isotopic signal of $-17.1 \%$, while the carbon isotopic composition changed to a more enriched benthic signal $(-10.7 \%)$ in adults, indicating a transition from larval pelagic life to a benthic habitat. Tissue isotopic composition approaches the end member macrobenthic food signatures asymptotically over time, with a time lag of around 8 mo (minimum juvenile age at settlement to minimum adult age, see 'Data analysis'), corresponding to the dilution of the pelagic carbon signature. A limited number of studies have estimated isotopic turnover rates for fish, particularly in natural conditions. M. flavolineatus time to equilibrium is in the range found for various fish species (see Herzka 2005), and is close to the value determined for populations of the migratory goby Rhinogobius spp. (Maruyama et al. 2001). Most of the size-dependent changes in $\delta^{13} \mathrm{C}$ occur at the young adult stage, for individuals with TL $<13 \mathrm{~cm}$ (breakpoint of the non-linear curve fit), that are expected to have a reef flat residence time of around 3.5 mo based on a von Bertalanffy growth curve (Holland et al. 1993). This provides evidence for relatively slow carbon turnover rate in $M$. flavolineatus, which is in agreement with the isotope mixing model where pelagic POM was still found to significantly contribute to the diet of young adults (mean pelagic POM diet contribution for juveniles and young adults of 47.7 and $17.0 \%$, respectively). While isotopic changes occur rapidly from juveniles to young adults with $\mathrm{TL}<13 \mathrm{~cm}$, larger individuals $(\geq 13 \mathrm{~cm} \mathrm{TL}$ ) took longer to reach the end member benthic carbon signature $(5.5 \mathrm{mo})$. Such $\delta^{13} \mathrm{C}$ patterns may be due to a decrease in $M$. flavolineatus growth rates with increasing size (Holland et al. 1993) or energy allocation for reproduction, as we found that $50 \%$ of young adults at $13 \mathrm{~cm}$ TL have already differentiated gonads. This was supported by the significant differences observed in $\delta^{13} \mathrm{C}$ values between non-sexually differentiated $(-15.2 \%)$ and sexually differentiated $(-13.8 \%)$ young adults. Even less is known about such physiological changes; this variation may be related to the equilibrium between assimilation and excretion, which is influenced by growth rate or metabolism (Olive et al. 2003). Physiological changes may also influence tissue ${ }^{13} \mathrm{C} /{ }^{12} \mathrm{C}$ isotopic ratios through variation in ${ }^{13} \mathrm{C}$ depleted lipid content relative to other biochemical components (DeNiro \& Epstein 1978, Pinnegar \& Polunin 1999), such as those implied in reproductive organs. Such findings highlight that ontogenetic dietary changes related to settlement occur at different rates within the $M$. flavolineatus population at La Saline reef. These rates appear to be highly dependent on physiological factors, in particular for the mediumsized individuals.

Overall positive relationships between $\delta^{15} \mathrm{~N}$ values and size have been found for Mulloidichthys flavolineatus. The $\delta^{15} \mathrm{~N}$ values of this fish typically increased with body size and such patterns have been attributed almost exclusively to ontogenetic changes in diet (e.g. Vander Zanden \& Rasmussen 2001, Badalamenti et al. 2002). Although some studies have pointed at a possible ${ }^{15} \mathrm{~N}$ accumulation with age (Beaudoin et al. 1999, Overman \& Parrish 2001), we did not find significant enrichment within each size group. There were no significant differences in $\delta^{15} \mathrm{~N}$ values between juveniles and young adults, and these groups thus had similar trophic level positions (mean trophic levels of 2.6 and 2.5, respectively), consistent with their high diet overlap ( 0.993 by number, 0.943 by volume) revealed by prey taxonomic analysis. The slight decrease in $\delta^{15} \mathrm{~N}$ values during the transition from juvenile to young adult stages reflects the shift from an offshore pelagic food source to an increasing reliance on benthic primary consumers (micro-/meiofauna), which generally have lower $\delta^{15} \mathrm{~N}$ values than their pelagic counterparts $\left(\delta^{15} \mathrm{~N}\right.$ mean of 3.3 and $4.4 \%$ for micro-/meiofauna proxy and pelagic POM, respectively; Vander Zanden \& Rasmussen 1999). Since a single trophic level is represented by a shift from 2 to $5 \%$ between predator and prey (Post 2002), the average shift of $3.4 \%$ in $\delta^{15} \mathrm{~N}$ values observed between the smallest size groups and adults (mean trophic level of 3.8 ) is about one trophic level and would represent the trophic status of the prey they consumed. While total prey number decreases by up to $50 \%$ between young adults and adults, the number of macrofauna prey items (mainly isopods, gastropods and ophuiroids) increases to a factor of 5.3 (1.0 between juveniles and young adults). Isotopic mixing models reveal that macrofauna food sources contribute significantly to the tissue isotopic composition of each size group and attain a contribution of up to $82.4 \%$ in the adult's diet. This is consistent with the commonly observed trend that the trophic level of most aquatic species 
increases with size (Jennings et al. 2002). These results suggest that $M$. flavolineatus gradually shifts to a macrofaunal diet that is totally equilibrated at the adult stage and reveal a major nutritional role of macrofauna in all post-settlement stages. This concurs with conclusions from stomach content analysis based on volume, but contradicts numerical analysis. While nematodes, tanaids and harpacticoid copepods (meiofauna) numerically dominated the diet, polychaetes (macrofauna) were dominant in volume, which was reflected in the fish isotopic signature. Polychaetes likely drive the juvenile yellowstripe goatfish isotopic signatures, since there were very few other macrofauna taxa present in their stomachs (only Naticidae, with low volumetric and numeric importance). In accordance with Sorden (1982), we suggest that $M$. flavolineatus preferentially select polychaetes. A possible preference could be based on the specific micronutrient fatty acids value necessary to support their growth (Watanabe et al. 1983).

Two distinct adult groups were identified based on their nitrogen stable isotope values $(11.9 \pm 0.8$ and $7.8 \pm 0.6 \%$ ). They displayed a range of sizes that excludes an age-related phenomenon, and we did not find any other discriminating factors (stomach contents, sex effect or time and place of capture) to explain such a difference. $\delta^{15} \mathrm{~N}$ isotope variability within the adult group could be explained by the migration of some individuals (individuals with $\delta^{15} \mathrm{~N}$ values of about $7.8 \%$ ) to outer reef soft-bottom areas, which have a more depleted $\delta^{15} \mathrm{~N}$ benthic food web baseline due to the increased distance from productive inner reef zones and anthropogenic runoffs (Heikoop et al. 2000). Holland et al. (1993) demonstrated that Mulloidichthys flavolineatus specimens presented a high degree of site fidelity, a relatively high feeding excursion distance range of $600 \mathrm{~m}$ across sand flats and very little post-recruitment movement of adults at Coconut Island reef, Hawaii. Hence, we hypothesize that fish in the present study with lower $\delta^{15} \mathrm{~N}$ values consisted of individuals primarily established in the outer reef zone that were caught during their daily feeding excursions in the shallow-water reef. In addition to ontogenetic dietary shifts, stable isotope analysis highlighted possible stage-specific partitioning in habitat use inside the La Saline reef that should be further investigated with tracking experiments.

\section{CONCLUSIONS}

The common use of prey numbers in stomach content analysis reveals strong limitations to the understanding of the feeding regime of Mulloidichthys flavolineatus and is at odds with conclusions from stable isotope analysis in giving too much importance to meiofauna. Volumetric analysis of diet composition appears to be more adequate, highlighting a major role of polychaetes in the diet of $M$. flavolineatus. Stable isotope analyses revealed that $M$. flavolineatus shift from a pelagic to a macrobenthic diet, which is equilibrated at the adult stage. Combined $\delta^{13} \mathrm{C}$ and $\delta^{15} \mathrm{~N}$ analysis is a relevant tool to depict dietary shifts occurring during ontogeny and migration onto the reef flats. We thus suggest that patterns of isotopic changes in response to dietary shifts of demersal reef fish can be adequately predicted based on size cohorts. We suggest that metabolism and sexual maturity can influence the rate at which isotopic equilibrium is reached following a shift to isotopically distinct food sources and should be take into account in further trophodynamic studies. Such dietary shifts following habitat change reflects a variety of factors, including variation in taxonomic composition and trophic level of prey, foraging behaviour, pelagic-benthic differences in the dominant sources of primary production and isotopic composition of the inorganic nutrient pools. Stable isotope analysis appears to be a useful tool to investigate habitat and resource partitioning, in particular to describe patterns of transition from offshore pelagic to benthic habitats and to evaluate the contribution of benthic production that supports fish biomass.

Acknowledgements. This research was funded by the French Regional Council of La Reunion Island. J.K. was also supported by the European Social Fund through a PhD grant. The authors thank 'Les Jardiniers du lagon' for their field assistance during sampling, and Dr. E. Cordier for providing the map files. Drs. S. Jaquemet and J. Richard are thanked for helpful suggestions on a draft of the manuscript.

\section{LITERATURE CITED}

Badalamenti F, D'Anna G, Pinnegar JK, Polunin NVC (2002) Size-related trophodynamic changes in three target fish species recovering from intensive trawling. Mar Biol 141:561-570

Baron J, Clavier J, Thomassin BA (1993) Structure and temporal fluctuations of two intertidal seagrass-bed communities in New Caledonia (SW Pacific Ocean). Mar Biol 117:139-144

Beaudoin CP, Tonn WM, Prepas EE, Wassenaar LI (1999) Individual specialization and trophic adaptability of northern pike (Esox lucius): an isotope and dietary analysis. Oecologia 120:386-396

Ben-Eliahu MN, Golani D (1990) Polychaetes (Annelida) in the gut contents of goatfishes (Mullidae) with new polychaete records for the Mediterranean coast of Israel and the Gulf of Elat (Red Sea). PSZN I: Mar Ecol 11:193-205

> Byström P, Garcia-Berthou E (1999) Density dependent growth and size specific competitive interactions in young fish. Oikos 86:217-232

Clarke KR, Gorley RN (2006) PRIMER v6: user manual/ tutorial. Primer-E, Plymouth

Cocheret de la Morinière E, Pollux BJA, Nagelkerken I, Hem- 
minga MA, Huiskes AHL, van der Velde G (2003) Ontogenetic dietary changes of coral reef fishes in the mangroveseagrass-reef continuum: stable isotopes and gut-content analysis. Mar Ecol Prog Ser 246:279-289

Coull BC (1999) Role of meiofauna in estuarine soft-bottom habitats. Aust J Ecol 24:327-343

$>$ DeNiro MJ, Epstein S (1978) Influence of diet on the distribution of carbon isotopes in animals. Geochim Cosmochim Acta 42:495-506

Durville P (2002) Colonisation ichtyologique des platiers de La Réunion et biologies des post-larves de poissons coralliens. PhD dissertation, Université de La Réunion, La Réunion

Eggold BT, Motta PJ (1992) Ontogeny dietary shifts and morphological correlates in stripped mullet, Mugit cephalus. Environ Biol Fishes 34:139-158

France RL (1995) Carbon-13 enrichment in benthic compared to planktonic algae: foodweb implications. Mar Ecol Prog Ser 124:307-312

Fry B (1983) Fish and shrimp migrations in the northern Gulf of Mexico analyzed using stable $\mathrm{C}, \mathrm{N}$, and $\mathrm{S}$ isotope ratios. Fish Bull 81:789-801

Fry B (2006) Stable isotope ecology. Springer, New York

> Fry B, Arnold CR (1982) Rapid ${ }^{13} \mathrm{C} /{ }^{12} \mathrm{C}$ turnover during growth of brown shrimp (Penaeus aztecus). Oecologia 54:200-204

Fry B, Mumford PL, Tam F, Fox DD, Warren GL, Havens KE, Steinman AD (1999) Trophic position and individual feeding histories of fish from Lake Okeechobee, Florida. Can J Fish Aquat Sci 56:590-600

Fry B, Baltz DM, Benfield MC, Fleeger JW, Gace A, Haas HL, Quiñones-Rivera ZJ (2003) Stable isotope indicators of movement and residency for brown shrimp (Farfantepenaeus aztecus) in coastal Louisiana marshscapes. Estuaries Coasts 26:82-97

Gannes LZ, O'Brien DM, Martínez del Rio C (1997) Stable isotopes in animal ecology: assumptions, caveats, and a call for more laboratory experiments. Ecology 78:1271-1276

> Golani D, Galil B (1991) Trophic relationships of colonizing and indigenous goatfish (Mullidae) in the eastern Mediterranean with special emphasis on decapod crustaceans. Hydrobiologia 218:27-33

Gosline WA (1984) Structure, function, and ecology in the goatfishes (family Mullidae). Pac Sci 38:312-323

- Harmelin-Vivien M, Kaim-Malka RA, Ledoyer M, JakobAbraham SS (1989) Food partitioning among scorpaenid fishes in Mediterranean seagrass beds. J Fish Biol 34: 715-734

Heikoop JM, Risk MJ, Lazier AV, Edinger EN and others (2000) Nitrogen-15 signals of anthropogenic nutrient loading in reef corals. Mar Pollut Bull 40:628-636

Herzka SZ (2005) Assessing connectivity of estuarine fishes based on stable isotope ratio analysis. Estuar Coast Shelf Sci 64:58-69

Herzka SZ, Holt GJ (2000) Changes in isotopic composition of red drum (Sciaenops ocellatus) larvae in response to dietary shifts: potential applications to settlement studies. Can J Fish Aquat Sci 57:137-147

Herzka SZ, Holt GJ, Holt SA (2002a) Stable isotope ratios as tracers of migration during the early life stages of marine fishes. Fish Sci 68:182-185

> Herzka SZ, Holt SA, Holt GJ (2002b) Characterization of settlement patterns of red drum Sciaenops ocellatus larvae to estuarine nursery habitat: a stable isotope approach. Mar Ecol Prog Ser 226:143-156

> Hesslein RH, Capel MJ, Fox DE, Hallard KA (1991) Stable isotopes of sulfur, carbon and nitrogen as indicators of trophic level and fish migration in the Lower Mackenzie River Basin, Canada. Can J Fish Aquat Sci 48:2258-2265 Hesslein RH, Hallard KA, Ramlal P (1993) Replacement of sulfur, carbon, and nitrogen in tissue of growing broad whitefish (Coregonus nasus) in response to a change in diet traced by $\delta^{34} \mathrm{~S}, \delta^{13} \mathrm{C}$, and $\delta^{15} \mathrm{~N}$. Can J Fish Aquat Sci 50: 2071-2076

Hobson KA, Welch HE (1992) Determination of trophic relationships within a high Arctic marine food web using $\delta^{13} \mathrm{C}$ and $\delta^{15} \mathrm{~N}$ analysis. Mar Ecol Prog Ser 84:9-18

Holland KN, Peterson JD, Lowe CG, Wetherbee BM (1993) Movements, distribution and growth rates of the white goatfish Mulloides flavolineatus in a fisheries conservation zone. Bull Mar Sci 52:982-992

Humann P, DeLoach N (2002) Reef fish identification, 3rd edn. New World Publications, Jacksonville, FL

Huss M, Byström P, Persson L (2008) Resource heterogeneity, diet shifts and intra-cohort competition: effects on size divergence in YOY fish. Oecologia 158:249-257

Jennings S, Pinnegar JK, Polunin NVC, Warr KJ (2002) Linking size-based and trophic analyses of benthic community structure. Mar Ecol Prog Ser 226:77-85

> Kolasinski J, Rogers K, Frouin P (2008) Effects of acidification on carbon and nitrogen stable isotopes of benthic macrofauna from a tropical coral reef. Rapid Commun Mass Spectrom 22:2955-2960

Krebs CJ (1998) Ecological methodology, 2nd edn. AddisonWelsey, Menlo Park, CA

> Kulbicki M, Bozec YM, Labrosse P, Letourneur Y, Mou-Tham G, Wantiez L (2005) Diet composition of carnivorous fishes from coral reef lagoons of New Caledonia. Aquat Living Resour 18:231-250

Letourneur Y (1996) Dynamics of fish communities on Reunion fringing reefs, Indian Ocean. I. Patterns of spatial distribution. J Exp Mar Biol Ecol 195:1-30

> Lorrain A, Savoye N, Chauvaud L, Paulet YM, Naulet N (2003) Decarbonation and preservation method for the analysis of organic $\mathrm{C}$ and $\mathrm{N}$ contents and stable isotope ratios of low-carbonated suspended particulate material. Anal Chim Acta 491:125-133

> Lukoschek V, McCormick MI (2001) Ontogeny of diet changes in a tropical benthic carnivorous fish, Parupeneus barberinus (Mullidae): relationship between foraging behaviour, habitat use, jaw size, and prey selection. Mar Biol 138:1099-1113

- Maruyama A, Yamada Y, Rusuwa B, Yuma M (2001) Change in stable nitrogen isotope ratio in the muscle tissues of migratory goby, Rhinogobius sp., in a natural setting. Can J Fish Aquat Sci 58:2125-2128

> McCormick MI (1995) Fish feeding on mobile benthic invertebrates: influence of spatial variability in habitat associations. Mar Biol 121:627-637

McCormick MI (1998) Condition and growth of reef fish at settlement: Is it important? J Ecol 23:258-264

McCutchan JHJ, Lewis WMJ, Kendall C, McGrath CC (2003) Variation in trophic shift for stable isotope ratios of carbon, nitrogen, and sulfur. Oikos 102:378-390

Michener RH, Schell DM (1994) Stable isotope ratios as tracers in marine aquatic food webs. In: Lajtha $\mathrm{K}$, Michener $\mathrm{RH}$ (eds) Stable isotopes in ecology and environmental science. Blackwell Scientific Publications, Oxford

Minagawa M, Wada E (1984) Stepwise enrichment of ${ }^{15} \mathrm{~N}$ along food chains: further evidence and the relation between $\delta^{15} \mathrm{~N}$ and animal age. Geochim Cosmochim Acta 48:1135-1140

Moltschaniwskyj NA, Pecl GT (2003) Small-scale spatial and temporal patterns of egg production by the temperate 
loliginid squid Sepioteuthis australis. Mar Biol 142: 509-516

Munro JL (1976) Aspects of the biology and ecology of Caribbean reef fishes: Mullidae (goat fishes). J Fish Biol 9: 79-97

Olive PJW, Pinnegar JK, Welch R, Richards G, Polunin NVC (2003) Trophic step fractionation is the result of a dynamic equilibrium. J Anim Ecol 72:608-617

Overman NC, Parrish DL (2001) Stable isotope composition of walleye: ${ }^{15} \mathrm{~N}$ accumulation with age and area-specific differences in $\delta^{13} \mathrm{C}$. Can J Fish Aquat Sci 58:1253-1260

Parrish JD (1989) Fish communities of interacting shallowwater habitats in tropical oceanic regions. Mar Ecol Prog Ser 58:143-160

Phillips DL, Gregg JW (2003) Source partitioning using stable isotopes: coping with too many sources. Oecologia 136: 261-269

Pinnegar JK, Polunin NVC (1999) Differential fractionation of $\delta^{13} \mathrm{C}$ and $\delta^{15} \mathrm{~N}$ among fish tissue: implications for the study of trophic interactions. Funct Ecol 13:225-231

Platell ME, Potter IC, Clarke KR (1998) Do the habitats, mouth morphology and diets of the mullids Upeneichthys stotti and $U$. lineatus in coastal waters of south-western Australia differ? J Fish Biol 52:398-418

Post DM (2002) Using stable isotope methods to estimate trophic position: models, methods, and assumptions. Ecology 83:703-718

Post DM, Layman CA, Arrington DA, Takimoto G, Quattrochi J, Montana CG (2007) Getting to the fat of the matter: models, methods and assumptions for dealing with lipids in stable isotope analyses. Oecologia 152:179-189

Robertson AI, Blaber SJM (1992) Plankton, epibenthos and fish communities. Coast Estuar Stud 41:173-224

Sampey A, McKinnon AD, Meekan MG, McCormick MI (2007) Glimpse into guts: overview of the feeding of larvae of tropical shorefishes. Mar Ecol Prog Ser 339: 243-257

Editorial responsibility: Yves Cherel, Villers-en-Bois, France
Scotto di Carlo B, Costanzo G, Fresi E, Guglielmo L, Ianora A (1982) Feeding ecology and stranding mechanisms in two lanternfishes, Hygophum Oenoiti and Myctophurn punctaturn. Mar Ecol Prog Ser 9:13-24

Sorden CT (1982) Food specialization by Mulloides flavolineatus (Mullidae) at Midway Islands. In: Caillet GM, Simonstad CA (eds) Fish food habit studies. Proc 3rd Pacific Workshop. Washington Sea Grant Publication, University of Washington, Seattle, WA, p 228-234

Svanbäck R, Persson L (2004) Individual diet specialization, niche width and population dynamics: implications for trophic polymorphisms. J Anim Ecol 73:973-982

Taddei D (2006) Transfert de matière et d'énergie dans les sédiments d'un complexe réfical anthropisé (île de La Réunion, Océan Indien). PhD dissertation, University of La Réunion, La Réunion

Vander Zanden MJ, Rasmussen JB (1999) Primary consumer $\delta^{13} \mathrm{C}$ and $\delta^{15} \mathrm{~N}$ and the trophic position of aquatic consumers. Ecology 80:1395-1404

Vander Zanden MJ, Rasmussen JB (2001) Variation in $\delta^{15} \mathrm{~N}$ and $\delta^{13} \mathrm{C}$ trophic fractionation: implications for aquatic food web studies. Limnol Oceanogr 46:2061-2066

> Vetter EW (1994) Hotspots of benthic production. Nature 372:47

Wahbeh MI (1992) The food and feeding habits of the goatfishes, Mulloides flavolineatus and Mulloides vanicolensis in the Gulf of Aqaba, Jordan. Senckenb Marit 22:245-254

Watanabe T, Kitajima C, Fujita S (1983) Nutritional values of live organisms used in Japan for mass propagation of fish: a review. Aquaculture 34:115-143

> Wells RJD, Cowan JH Jr, Fry B (2008) Feeding ecology of red snapper Lutjanus campechanus in the northern Gulf of Mexico. Mar Ecol Prog Ser 361:213-225

Zaret TM, Rand AS (1971) Competition in tropical stream fishes: support for the competitive exclusion principle. Ecology 52:336-342

Submitted: December 12, 2008; Accepted: April 24, 2009 Proofs received from author(s): June 24, 2009 